\title{
THE LEX CORNELIA DE INIURIIS AND "HYPERLINKS" IN ROMAN LAW
}

\author{
Jacob Giltaij*
}

\section{ABSTRACT}

The development of modern technology has resulted in some interesting new legal problems, such as whether using a hyperlink on a website to libellous material amounts to punishable defamatory libel. This article asks the question if there are analogous cases and rules to be found in the Roman law of insult to these novel forms of indirect or veiled modes of defamatory libel. It appears that specifically indirect forms of insult were not punished by means of the private delict iniuria but rather by the republican crimen formulated in the lex Cornelia de iniuriis. A senatus consultum in the early principate then either enhanced the scope of the lex Cornelia, or effected the application of the lex lulia de maiestate to these indirect modes of insult. The article contends that the ground for the senatus consultum may tell us something about the division between "public" and "private" in Roman law, and perhaps even Roman society in general.

Keywords: Defamatory libel; insult; iniuria; lex Cornelia de iniuriis; crimen laesio maiestatis; Augustus

* Post-doctoral researcher at the Academy of Finland-funded (decision 312154) Centre of Excellence in Law, Identity and the European Narratives (EUROSTORIE) at the Faculty of Social Sciences of the University of Helsinki. 


\section{Introduction}

In 2009, the Court of Appeal for British Columbia in Canada delivered a judgment in the case of Crookes v Newton. ${ }^{1}$ The appeal was lodged by Crookes, a politician in the Canadian Green Party, against Newton, the owner and operator of a website, but also the author of an article regarding the politics of Crookes. The case was one of defamatory libel. It was, however, not the article itself that was considered libellous by Crookes, but the content of websites behind various hyperlinks in the article written by Newton. The question the Court faced was whether hyperlinking to these websites alone constituted publication of their content, therefore making Newton liable for defamatory libel. Thus, in Crookes $v$ Newton an interesting point of law was raised, namely whether the mere reference to potentially libellous material should be punishable, that is, constitutes publication, even if the person publishing it did not overtly agree with, support or perhaps even know its content. Although the matter was raised in a thoroughly modern context, hyperlinking to other websites, the point of law may well be extended into the legal historical sources. The Canadian Court suggested as much in 2009 by employing an English case from well before the invention of websites in delivering its judgment. ${ }^{2}$ In Hird $v$ Wood from 1894, a man sat at a road pointing to an insulting placard hanging next to him at passers-by. According to the court the mere act of referring to the placard constituted a form of publication, and the man was therefore held liable for defamatory libel. Hird $v$ Wood notwithstanding, neither the Court of Appeal for British Columbia nor the Supreme Court of Canada - two years later - found Newton to be liable for defamatory libel, stating that the usage of hyperlinks is to be likened to footnotes, and is not in and of itself a publication of the content they refer to. The goal of this article is to extend the scope of the point of law raised in Crookes $v$ Newton and to look at what the Roman legal sources have to say regarding the liability for whoever publishes libellous material rather than the one composing it. ${ }^{3} \mathrm{I}$ will do this by first looking at the

$1 \quad$ Crookes $v$ Newton 2009 BCCA 392.

2 Crookes $v$ Newton at 392 no 84: "I agree, as well, that the circumstances of a case may add more so as to demonstrate that a particular hyperlink is an invitation or encouragement to view the impugned site, or adoption of all or a portion of its contents. For example, in Hird v Wood (1894) 38 SJ 234 (CA), referred to in Carter, evidence of the defendant pointing to a placard with content was held to be sufficient evidence of publication to demonstrate that a particular hyperlink is an invitation or encouragement to view the impugned site, or adoption of all or a portion of its contents (...) So a statement to the effect ' $\mathrm{N}$ is described at [hyper link]' may itself incorporate a libel so as to be defamatory."

3 For comparisons between iniuria and versions of libel and slander in the common law, see Zimmermann 1996: 1074-1078; Descheemaeker \& Scott 2013: 26-31 in particular; and Ibbetson 2013: 33-48: "The component parts are there, but they have not begun to be digested into anything like a single whole" and naming "defamation" (36). For South-African law, there is actually a direct connection: Scott 2013: 119-139. For Dutch law, see the recent case of Paay tegen Geenstijl Media et al (RB Amsterdam 25.7.2018), where the latter website linked to previously published libellous content. Modern technology has led to a number of analogous and similar legal problems, such as "revenge porn", see eg Brown 2018. 
notion of libellus famosus in general, which would to a degree be the equivalent of defamatory libel in Roman law. Then, I shall discuss some of the legal texts in which a similar situation as the one the Court of Appeal for British Columbia was presented with seems to occur. As we shall see, the problem of publication actually leads to an interesting technical problem in Roman legal sources, namely by virtue of it being one of the manifestations of iniuria (physical abuse and insult) which was apparently not punishable by a private delictum, but rather under the lex Cornelia de iniuriis, which was at least, to a degree, a public crimen. It could therefore, in the words of Buckland, ${ }^{4}$ be one of a "variety of cases" where the content of a private delict and a public crime differ from one another. The main queries of this article then read: "[W]hy does publishing an insult seem to be a public crime, whereas composing the same insult constituted a private delict, and what does that say concerning the relations between the lex Cornelia de iniuriis and the iniuria of the Praetorian Edict, crimes and delicts in the Roman legal order, and the notions of 'public' and 'private' in Roman law and society in general?"

\section{Insult in Roman law}

Even though the original delict in the Roman law of the XII Tables primarily punished physical injuries, ${ }^{5}$ insult came to be a foremost category of iniuria. This is evidenced by the equation of iniuria with contumelia meaning "injury to someone else's person" in a general sense by the late republican jurist Labeo. ${ }^{6}$ The situation is complicated, however, by the fact that physical injuries can amount to insults, that is, affronting one's honour. We can see this most clearly in the flogging of someone else's slave amounting to an insult to his master. ${ }^{7}$ The pure insult, namely without inflicting physical harm, may fall under one of two categories of the Edict of the praetor: convicium, which seem to be primarily and specifically defined verbal injuries, ${ }^{8}$ and infamandi causa factum, anything that brings someone else into disrepute. ${ }^{9}$ Ulpian indicates that the difference between these two modes of insult consists of whether or not something is shouted loudly in a crowd: if this is the case, the praetor can extend the actio iniuriarum for convicium..$^{10} \mathrm{I}$ will, however, focus on more indirect forms of insult, which in the case of an insulting song was at least a part of the broad category of infamandi causa factum. ${ }^{11}$ The same goes for its publication (carmen proponere), although with Raber I take "publication" here to

4 Buckland 1963: 590-591.

5 Zimmermann 1996: 1050-1051; Hagemann 1998: 1-2.

6 See G 1 141; Coll 25 1. See, further, Hagemann 1998: 64-67; Ibbetson 2013: 40 (“disrespect”).

7 G 3 222; D 4710 15 46; Hagemann 1998: 65, 84. Not always: D 47101535.

8 See D 471015 4: Hagemann 1998: 68-71. Present in the XII Tables: Zimmermann 1996: 1053 1054 .

9 D 471015 27: Lenel 1927: 401, par 103; Hagemann 1998: 75-81.

10 D 471015 12: Zimmermann 1996: 1054; Hagemann 1998: 69.

11 D 471015 27: Raber 1969: 60; Zimmermann 1996: 1056-1057; Hagemann 1998: 78. 
mean the actual performance of the song, in which case the source and the purpose of the insult is relatively clear, making it less relevant for my argument. Then, again, the rubric of infamandi causa factum has an interesting feature that distinguishes it from the other rubrics, namely that a subjective intent of insult seems to be the only element necessary for the culprit to be liable. ${ }^{12}$ In other words, the transgression under the rubric is so broadly defined that it is difficult to imagine that our situation - insult by publishing or referring to another source - would not have been covered by it. Focusing on the written insult, ${ }^{13}$ only in a single legal source, not in the Digest, a measure of connection is made between the rubric infamandi causa factum and the written pamphlet. ${ }^{14}$ The content of this source, however, is directly relevant to our argument. First of all, this is because the text seems to distinguish between the verbal and written insult, or the carmen ${ }^{15}$ and libellus famosus ${ }^{16}$. Second, the text is interesting because in the case of the song it is primarily the composer who is punished, ${ }^{17}$ whereas the culprit who is punished for a libellus famosus is the one who is "publishing" (proposuerint) it. We already came across the term proponere earlier, and it seems to indicate the spreading of it in a very wide sense, not just writing or performing the libellus. ${ }^{18}$ Therefore, a degree of analogy to our problem of hyperlinks could be argued in regard to this text. This is all the more the case seeing that the trial in which the publication of the libellus famosus is punished appears to be a criminal rather than a private one: the penalty consists of relegation to an island. However, this could also at first glance be taken as proof that the connection between the Edict rubric and the libellus stems from the post-classical era, when the cognitio had definitively taken over the formula-trial. Yet, there is a counter-argument to be made, to the extent that publishing the libellus famosus in whatever form during the classical era actually was not punished by means of a private actio iniuriarum in the context of ne infamandi causa, but under the lex Cornelia de iniuriis. In a text seemingly in the context of the lex Cornelia, Ulpian states that anyone who writes, composes or publishes (scripserit composuerit ediderit dolove malo fecerit) a book pertaining to the disgrace of anyone (librum ad infamiam alicuius pertinentem) or brings it about that these things are done (quo quid eorum fieret), whether the publication will be in

12 D 471015 27; Raber 1969: 60-61 (60: „Der geistige Urheber des Produkts konnte von dem, der das Lied sang oder sonst wie verbreitete, verschieden sein“). Also, Scott 2013: 125-126, referring to Daube 1991.

13 Which would not emerge as a seperate category until Azo: see Descheemaeker/Scott 2013: 12.

14 PS 54 15-17. See also Raber 1969: 60; Hagemann 1998: 138-140, who then again does not seem to take G 3220 into account. D 47101544 is interesting, but clearly written in the context of qui servum alienum. Libellus in D 47101529 refers to the introductory form of the cognitio-trial: see Raber 1969: 63. This is despite the Digest-title actually reading De iniuriis et famosis libellis.

15 Pauli Sententiae 5415.

16 Pauli Sententiae 5417.

17 Hagemann 1998: 139: „Während in Par. 15 der Verfasser mit dem Verbreiter offenbare identisch ist."

18 Ibid: „schriftliche Verbreitungsart.“ 
anyone's name or anonymous (etiamsi alterius nomine ediderit vel sine nomine), he will be punished under the statute by the inability to testify in open court. ${ }^{19}$ The wording suggests Ulpian might be referring to the original text of the lex here, but this is notoriously difficult to determine. Also, it should be indicated that the term libellus famosus is actually not used here, but the rather synonymous "liber ad infamia pertinens". ${ }^{20}$ Thirdly, whereas pseudo-Paul agrees that the Edict employs proponere, if Ulpian is more true to its wording and intent, the lex Cornelia apparently entailed a wider set or at least a myriad of more specific forms of "publication". ${ }^{21}$ Moreover, even otherwise arranging for the publication and irrespective whether or not the original author is referred to or known to the person publishing, the writing is liable under the statute. Thus, the application of the lex Cornelia is very wide; even wider perhaps than the analogous Edict rubric ne quid infamandi causa fiat which concerned any action by which another man would incur infamy. ${ }^{22}$ We do not possess much information on the scope and functioning of the lex Cornelia de iniuriis at any stage of its development. It seems certain that by the time of pseudo-Paul the lex had been subsumed completely under the private delict of iniuria in the cognitio-trial. ${ }^{23}$ In the era of Ulpian, however, it is less obvious to assume that the lex had ceased to function as an autonomous entity, if only because the largest extant series of fragments is handed down in a text composed by Ulpian himself, albeit one written in the context of his commentary on the Edict. ${ }^{24}$ There is no obvious concrete "Klagenkonkurrenz" between the actio iniuriarum and the (private law-modelled) actio ex lege Cornelia de iniuriis, save perhaps in some obscure cases in Cicero concerning physical injuries. ${ }^{25}$ However, speaking against the lex Cornelia de iniuriis as a dead letter already in Ulpian's time, are the small but significant differences between the application of iniuria as a public crime and as a private delict, such as

19 D 47105 9: Si quis librum ad infamiam alicuius pertinentem scripserit composuerit ediderit dolove malo fecerit, quo quid eorum fieret, etiamsi alterius nomine ediderit vel sine nomine, uti de ea re agere liceret et, si condemnatus sit qui id fecit, intestabilis ex lege esse iubetur; Mommsen 1899: 800, who however assumes the lex in question is the Law of the XII Tables (nt 3). On this see Raber 1969: 61; Von Lübtow 1969: 159; Bauman 1970: 254, n 30 (D 4710 5, clearly the lex Cornelia de iniuriis); and Liebs 1972: 270-271. However, I do not agree that from this it follows that the penalty in the lex itself already was intestability, see below. This is not mentioned in Pugliese 1941. Daube 1991 (at 467) states as follows: "[T]he lex Cornelia de iniuriis dealt only with pulsare, verberare, domum vi introire."

20 Libellus famosus is probably a post-Augustan invention: see Daube 1991: 465, 469.

21 The term used here is edere, the meaning of which, however, does not seem to differ fundamentally with regard to proponere; indeed Heumann \& Seckel actually refer to D 471059 in the context of the former, and not the latter, notion.

22 Compare D 4711 1 1: Daube 1991: 469-471.

23 See, however, PS 54 8; and Buckland 1963: 590.

24 D 4710 5pr-11 from Book 56: Lenel 1889 II: col 767-768, nos 1337 ( pr -8) and 1338 (8-11).

25 Miglietta 2001: 102, 189-190. Compare Liebs 1972: 270-271. Hackl has argued for D 471071 actually entailing a concurrence between iniuria under the Edict and under the lex: Hackl 1972: 170-172. 
the aforementioned category of vi domum introire as well as the structure of the claim. ${ }^{26}$ For example, as late as the second century AD, slaves are explicitly excluded from a prosecution under the lex Cornelia de iniuriis; a harsher punishment awaiting them extra ordinem. ${ }^{27}$ Furthermore, as will be set out below, there apparently was a necessity in the first century AD to expand on the lex Cornelia de iniuriis by means of a senatus consultum. Finally, generally speaking, according to the literature both forms of iniuria probably existed alongside each other for quite a long period of time. ${ }^{28}$ Among these instances of iniuria the lex probably had a wider or different scope than the private delict, and we can therefore also include Ulpian's statement in D 471059 as regarding any form of publication of a book pertaining to the disgrace of anyone. Under the rubric ne quid infamandi causa fiat, the publication of poems that injure anyone's modesty was punishable (carmen proponere quod pudorem alicuius laedat).$^{29}$ In that context, Daube gives a series of analogous texts I understand to be by-and-large outside the scope of the Edict rubric. Among these is D 471059 , as well as G 3220 and D 471015 44, dealing with insults and physical injuries done to a slave. ${ }^{30}$ The fourth of these texts seems to be very interesting to our query: In D 47106 , a senatus consultum is stated by means of which it was determined that when the name of the victim is not mentioned in the insult, a public quaestio must be the place of prosecution (voluit senatus publica quaestione rem vindicari). When the name of the victim is, however, stated, the private legal remedy is the path to follow (ceterum si nomen adiectum sit et iure communi iniuriarum agi poterit). ${ }^{31}$ The text makes it clear that the public and private forms of legal protection are mutually exclusive. ${ }^{32}$ Thus, as Daube states, the text concerns the public law aspect and the private law aspect in cases of insult by publication. ${ }^{33}$ Given the texts I have discussed above, it seems certain that the public prosecution referred to here is a trial under the lex Cornelia de iniuriiis. ${ }^{34}$

26 D 3342 1: ad actionem iniuriarum ex lege Cornelia procurator dari potest nam etsi pro publica utilitate exercetur, privata tamen est. See Pugliese 1941: 117f, 120 (D 422124 (reum recipere), 122; Hagemann 1998: 63.

27 D 48212 4; Pugliese 1941: 152.

28 Mommsen 1899: 803-808; Buckland 1963: 591.

29 D 471015 27; Daube 1991: 473.

30 Daube 1991: 473-474.

31 Quod senatus consultum necessarium est, cum nomen adiectum non est eius, in quem factum est: tunc ei, quia difficilis probatio est, voluit senatus publica quaestione rem vindicari. Ceterum si nomen adiectum sit, et iure communi iniuriarum agi poterit: nec enim prohibendus est privato agere iudicio, quod publico iudicio praeiudicatur, quia ad privatam causam pertinet. Plane si actum sit publico iudicio, denegandum est privatum: similiter ex diverso.

32 Kaser/Hackl 1996: 186; Mommsen 1899: 801 n 4.

33 Daube 1991: 473-474. Note that the text states a quaestio. Placed in the context of Paulus' Commentary on the Edict rubric Ne quid infamandi causa fiat; Lenel 1889 I: col 1072, col 685.

34 Despite Mommsen 1899: 804 designating the trial under the lex as "not a iudicium publicum" due to the character of the charge as exclusive to the violated party. 


\section{The lex Cornelia de iniuriis and a senatus consultum}

There is all the more reason to assume this, seeing one of the texts in book 56 of Ulpian's commentary on the Edict regarding the lex Cornelia also refers to a senatus consultum. ${ }^{35}$ The text states that a senatus consultum extends the same punishment (eadem poena ex senatus consulto tenetur) to those composing epigrams and unwritten insults (qui epigrammata aliudve quid sine scriptura in notam aliquorum produxerit), and even to those enabling the buying and selling of these things (qui emendum vendendumve curaverit). The relation to the preceding and subsequent texts in the Digest seems clear: the lex Cornelia de iniuriis punished the writing, composing or publishing of written insults both anonymous and signed, and what was most likely a single senatus consultum extended the penalty to specific other mediums (D 47105 10: short poems, sine scriptura) as well as the situation in which the name of the victim is not explicitly mentioned in the work (D 47106 ). Unclear, however, is the precise substantive relation to the Edict rubric ne quid infamandi causa fiat, mainly due to its apparent enormous scope: to a degree in accordance with Daube a distinction could be made on the basis of the specific purpose of the insult in question, the Edict rubric contrary to the lex penalising injuries with the intent of bringing infamia in its technical sense. ${ }^{36}$ Moreover, it remains to be seen whether or not the application of the lex is analogous to or exceeds the scope of the Edict rubric to the extent of concerning someone being punished for merely making reference to an insulting libellus, the central question I have posed in this article. For this, it seems prudent to take a closer look at the senatus consultum that the relevant texts have been citing. One of the reasons to do so is the reason given in D 47106 for distinguishing between a public prosecution and a private actio iniuriarum. According to Paul, this reason is simply a consideration of the difficulties of proof when someone is not named (quia difficilis probatio est). In any case, primarily it needs to be determined which senatus consultum Ulpian and Paul refer to here. Citing D 4710 6, Mommsen appears to state that handling an offensive carmen up until Augustus had been punished in a private trial. The emperor then by means of the senatus consultum brought both insulting carmina and libelli under the ambit of the lex Iulia de maiestate..$^{37}$ For this, he adduces two texts: Suetonius Augustus $55^{38}$ and Tacitus Annales 172 (in combination with Cassius Dio 56 27): ${ }^{39}$

35 D 47105 10: Eadem poena ex senatus consulto tenetur etiam is, qui epigrammata aliudve quid sine scriptura in notam aliquorum produxerit: item qui emendum vendendumve curaverit.

36 Daube 1991: 470-471. Following Daube himself, the terminology regarding the lex in D 471059 is however republican, and reads liber ad infamia pertinens.

37 Mommsen 1899: 565, 800.

38 Etiam sparsos de se in curia famosos libellos nec expavit et magna cura redarguit ac ne requisitis quidem auctoribus id modo censuit, cognoscendum posthac de iis, qui libellos aut carmina ad infamiam cuiuspiam sub alieno nomine edant. See, also, Bauman 1970: 251, 253.

39 The text and translation are from Church, Brodribb \& Bryant 1942. 
Tacitus Annales 1 72: Non tamen ideo faciebat fidem civilis animi; nam legem maiestatis reduxerat, cui nomen apud veteres idem, sed alia in iudicium veniebant, si quis proditione exercitum aut plebem seditionibus, denique male gesta re publica maiestatem populi Romani minuisset: facta arguebantur, dicta inpune erant. Primus Augustus cognitionem de famosis libellis specie legis eius tractavit, commotus Cassii Severi libidine qua viros feminasque inlustris procacibus scriptis diffamaverat; mox Tiberius, consultante Pompeio Macro praetor an iudicia maiestatis redderentur, exercendas leges esse respondit. Hunc quoque asperavere carmina incertis auctoribus vulgata in saevitiam superbiamque eius et discordem cum matre animum.

But he [= Tiberius, JG] did not thereby create a belief in his patriotism, for he had revived the law of treason, the name of which indeed was known in ancient times, though other matters came under its jurisdiction, such as the betrayal of an army, or seditious stirring up of the people, or, in short, any corrupt act by which a man had impaired "the majesty of the people of Rome". Deeds only were liable to accusation; words went unpunished. It was Augustus who first, under colour of this law, applied legal inquiry to libellous writings, provoked, as he had been, by the licentious freedom with which Cassius Severus had defamed men and women of distinction in his insulting satires. Soon afterwards, Tiberius, when consulted by Pompeius Macer, the praetor, as to whether prosecutions for treason should be revived, replied that the laws must be enforced. He too had been exasperated by the publication of verses of uncertain authorship, pointed at his cruelty, his arrogance, and his dissensions with his mother.

Paul in D 47106 can still be rhymed with Tacitus, since the text speaks only about a public prosecution in a very general sense, and can therefore also have referred to a punishment under the lex Iulia de maiestate. However, the Tacitus-text, in particular, seems to directly contradict Ulpian in D 471059 , at least provided the jurist is indeed writing in the context of the lex Cornelia de iniuriis and the historian discusses a procedure under the lex Iulia de maiestate. More specifically, by virtue of our query concerning the legal problem of "publishing" anonymous insults in Roman law, the Tacitus-text allows us to ask two questions, namely: (1) Was the anonymous or otherwise indirect insult not done to the princeps but to other Romans with a high social status seen as laesio maiestatis after the enactment of the senatus consultum in 6 AD?; and (2) Was the anonymous or otherwise indirect insult punished in the quaestio de maiestatis or the quaestio de iniuriis, if there was such a thing as the latter at all, or both? And on what criterion did the choice for following either procedure depend?

Reasoning from the texts we have adduced previously, Bauman in his work on the crimen laesio maiestatis provides an extensive discussion of the problem. In it, he strongly distinguishes between defamatory insults in written libri and libelli, and oral carmina, all of which were covered (as I understand already before Augustus) by the lex Cornelia de iniuriis; and the problems of the anonymous publisher and the unnamed victim, which were the topic of the Augustan senatus consultum extending the lex Cornelia de iniuriis. ${ }^{40}$ In accordance with the Tacitus-text, and following

40 Bauman 1970: 257. He dates the senatus consultum at 6 AD: 261. 
Mommsen and Bauman, in the latter case in practice the procedure under the lex Iulia de maiestate was followed, prompting references in the legal texts to it being publica (rem, utilitas), a sanction exceeding a mere fine, and allowing for informers rather than only the injured party bringing the charge. ${ }^{41}$ From this, it seems as if though the criterion for following either the procedure under the lex Cornelia de iniuriis, basically a private actio de iniuriis in Bauman, or the public prosecution by means of the quaestio de maiestate is whether the majesty of the Roman people was injured by the anonymous publication as Tacitus has it: The senatus consultum extending the lex Cornelia to all anonymous insults aimed at high status Romans in this reading is a trick played by Augustus to be able to punish anonymous lampoons on him, while retaining the semblance of the Roman republican criminal order by subsuming it under iniuria (ad infamiam alicuius) rather than laesio maiestatis (against the princeps himself).

\section{Defamatory libel and the adjudicative powers of Augustus}

Depending on what he means by specie legis, Tacitus Annales 172 provides strong support for this reading. However, there does seem to be a discrepancy between the content of the historical and the legal sources here. Though this could simply be an issue of transmission, there are no references to be found to (publishing) a (anonymous) famosus libellus being an instance of laesio maiestatis in the context of the actio iniuriarum, the lex Cornelia de iniuriis or the crimen laesio maiestatis. Rather, the legal sources suggest a rather unbroken trajectory from the date of the senatus consultum until at least the era of pseudo-Paul of a separate procedure of sorts under the lex Cornelia de iniuriis. Moreover, the procedure in question is designated publica (utilitatem) by Paul himself, ${ }^{42}$ suggesting at least its continued hybrid character, and the sanction went beyond the fine alone to intestability by virtue of the enhancing senatus consultum itself. ${ }^{43}$ In a more general sense, once it is accepted that the procedure under the lex Cornelia de iniuriis has both public and private aspects, the presence of informers does not have to preclude the privileged character of the accusatio (or rather the actio). All of this is not to say that Tacitus, Mommsen and Bauman are wrong. I do, however, wish to introduce a possibility to the discussion, namely that the procedure for anonymous insults was subsumed at a very early stage at least partly by the imperial cognitio-procedure. This suggestion does not minimise the difficulties to determine the type of legal procedure followed

41 Idem 254, 261-263. See, too, PS 54 17; D 47 10 6; and D 4710511.

42 D 33421.

43 D 281181 . See, also, D $22521 \mathrm{pr}$, that simply states: "(A) person who has been convicted of having written a libellous poem is incompetent to testify": Mommsen 1899: $800 \mathrm{n} 3$. It is possible that the penalty was already envisioned in the lex Cornelia itself: see Von Lübtow 1969: 158. 
for certain transgressions at some point in the early principate; quite the contrary: the measure of transference from ordinary quaestio to cognitio alone has been the subject of a long debate. ${ }^{44}$ To illustrate this debate, it suffices to look at D 47106 again as cited previously, in which there is talk of a quaestio rem vindicari, in a period during which it is highly unlikely that a quaestio either under the lex Cornelia de iniuriis or the lex Iulia de maiestate was still in existence. These difficulties are expedited when considering the transfer from formula-procedure to cognitio. Generally speaking, there probably was no meaningful transfer in the latter case before the era of Hadrian. As such, I suggest it is extremely valuable to look at the development of the more publicly defined categories of iniuria, particularly those that seemed to have been outside the scope of the private delictum, such as vi domum introire and the anonymous defamatory libel, not coincidentally the topic of this paper. There are several reasons for this: for example, we actually have an example of a more or less publicly-defined form of iniuria punished (in a cognitio) extra ordinem predating Augustus, being the prosecution of sorts of a criminal slave. ${ }^{45}$ Moreover, Mommsen suggests there was an early move by Augustus to prosecute in or preside over a criminal procedure pertaining to defamatory libel not concerning himself. ${ }^{46}$ The point of introducing the element of the cognitio regards the fact that Bauman's argument hinges on there still being a meaningful intent to distinguish between the procedural rules of the publicly defined version of iniuria and the quaestio de maiestate in this particular case during the early principate. However, to what extent was this actually relevant if the transgression in question was just taken up in the relatively open imperial cognitio? And reading from this perspective, is it perhaps possible to read the words of Tacitus more ambivalently, particularly considering he is writing at the start of the second century $\mathrm{AD}$, a period in which any distinction between various quaestiones was surely rendered minimal, if not irrelevant, already? It should be indicated here that Tacitus refers to an out-and-out cognitio in Annales $172 .{ }^{47}$ Following Tacitus, the first procedure for (anonymous) defamatory libel under the senatus consultum was that against an orator named Cassius Severus. The details of this trial (or trials) are severely muddled, the problem being that Seneca maior and Tacitus seem to suggest that Severus was acquitted at least on the first go, whereas Cassius Dio and Tacitus elsewhere refer to

44 Pugliese 1982: 735-746, discussing Tacitus Annales 172 at 751 as an instance of the lex Iulia de maiestate and insult punished in the cognitio at 777.

45 D 48214.

46 The reference is to Horace Satires 21 82. See Mommsen 1899: 801, and also Bauman 1970: 252: "(I)t is not certain that Horace intends a serious reference to any law." Also, the orator Cassius Severus (see below) had been involved in multiple seemingly criminal procedures involving insults: see Bauman 1970: 257-259. Lastly, already in 27/26 BC Gaius Cornelius Gallus is accused of hybris before Augustus: see Volkmann 1969: 113, 115-116.

47 Bauman 1970: 259. 
a condemnation and relegation..$^{48}$ In any case, three things seem certain: 1) at least one of the trials was conducted in Augustus's personal forum, namely his cognitio in the terminology of the second century AD;2) when Severus was convicted at least once for defamatory libel this was for an anonymous insult, at least if there was any relation to the new procedure under the senatus consultum at all; and 3) the insult was not aimed primarily at Augustus. Regardless of whether there was a technicallegal relation between the procedure and the crimen laesio maiestatis, by all accounts there was a practical one. After discussing the Severus-case, Cassius Dio proceeds with trials involving maiestas as such. ${ }^{49}$ Furthermore, from a recent overview of the cases in which emperors were involved in their judicial capacities in whichever shape or form it emerges there were several in which elements of defamatory libel and laesio maiestatis appear. ${ }^{50}$ As Bauman states: "It seems that Cassius [Severus, JG] was tried at a time when conspiracy was in the air." ${ }^{51}$ However, the anonymous insult, at least against Augustus himself, seems to have been dealt with before Severus. Suetonius refers to the cases of Junius Novatus and Cassius Patavinus, probably taking place in $6 \mathrm{AD} .{ }^{52}$ Novatus was punished with a fine for "publishing" (edidisset) a letter insulting Augustus under the name of a young Agrippa, whereas Patavinus had incurred a banishment for seditious talk at a public event. Seeing he was punished with a mere fine, it is likely that Tacitus is actually inaccurate in this instance, and that at least the case of Novatus did take place in Augustus's cognitio in whatever form it existed this early on under the senatus consultum enhancing the lex Cornelia de iniuriis Suetonius would allude to later, in Augustus 55. In any case, the cases are dated $6 \mathrm{AD}$, the same year in which the senatus consultum was enacted, fitting the apparent epidemic of (anonymous) lampoons in or around that year. ${ }^{53}$ Otherwise, it seems unclear precisely what connects the punishments inflicted on Novatus and Patavinus: a fine is too light for the crimen laesio maiestatis, whereas a banishment is too harsh for iniuria. Although the seditious element with respect to the transgression of Patavinus suggests an application of the lex Iulia de

48 See Bauman 1970: 259-260; Seneca maior, Controversiae 24 11; Cassius Dio 554 4; and Tacitus Annales 4215 (by a senate decree). According to Bauman 1970: 259, he was first acquitted for convicium, but then condemned in the cognitio de famosis libellis, and thereafter possibly condemned again while in exile on Crete.

49 Bauman 1970: 259; Cassius Dio 5544.

50 Interesting is the (fictional?) conviction and exile of Ovid, see Tuori 2016: 74-80.

51 Bauman 1970: 259.

52 Clementiae civilitatisque eius multa et magna documenta sunt. Ne enumerem, quot et quos diversarum partium venia et incolumitate donatos principem etiam in civitate locum tenere passus sit: Iunium Novatum et Cassium Patavinum e plebe homines alterum pecunia, alterum levi exilio punire satis habuit, cum ille Agrippae iuvenis nomine asperrimam de se epistulam in vulgus edidisset, hic convivio pleno proclamasset neque votum sibi neque animum deesse confodiendi eum. See, also, Bauman 1970: 253.

53 Cassius Dio 55 27; Bauman 1970: 260. 
maiestate ${ }^{54}$ this discrepancy in punishments for similar transgressions also fits an early iteration of a cognitio-procedure. Furthermore, with the case of Novatus, we are close to the situation postulated at the beginning of this article: the "publication" of the anonymous - in this case pseudonymous - insult. Regardless of Augustus's efforts going as far as publicly burning the insulting placards, it seems they remained endemic long after the enactment of the senatus consultum: whether or not connected to laesio maiestatis and whether or not aimed at the Emperor himself, defamatory libel continued to be a main subject matter in his cognitio even during his later life. ${ }^{55}$

\section{Conclusion}

In the introduction to this article I have asked a question based on a very modern problem of law: Would someone not insulting someone else directly but indirectly, by using a "hyperlink", be punished in Roman law, and if so, under what law or regulation? No concrete analogous case in Roman law was found in which someone had insulted someone else indirectly. I would say the closest we have gotten is the pseudonymous insult by Junius Novatus in Suetonius, Augustus 51. However, the pseudonymous insult was most likely made punishable by a senatus consultum enacted in $6 \mathrm{AD}$, during the reign of Augustus (D 47106 ). There is even a possibility that the pseudonymous insult was punished under the lex Cornelia de iniuriis from the time of its enactment (D 471059 ). In a general sense, the same appears to be the case for our legal problem, namely the punishment of the "publication" of the insult by someone else, someone who may not be aware of or in agreement with the insulting content: either the lex, the senatus consultum or the jurists refer to terms like proponere and edere in this context. If the original lex Cornelia de iniuriis has already punished the publication of the insult rather than its performance or composition, the question then becomes what the function of the later senatus consultum entailed. According to Mommsen and Bauman, the senatus consultum may have extended the scope of the libel to the lex Iulia de maiestate, for which they adduce Tacitus Annales 172 . Yet, there seems to be a discrepancy here with the content of the legal sources, which tend to refer (solely) to the lex Cornelia de iniuriis as late as Ulpian and Paul. Assuming Paul is talking about the 6 AD senatus consultum, the jurist actually provides a ground for its enactment: when the name of the author is not mentioned, the path to take is a public prosecution, because of difficulties of proof. However, the "Klagenkonkurrenz" in the text in question seems to be one between the actio ex lege Cornelia de iniuriis and the actio iniuriarum, since the text goes to the trouble to specify that the private option is iure communi: depending on the strength of this as an argument, at least it makes a form of indirect

54 Thus making it more than a simple convicium in the sense of D 47101512 as well.

55 Cassius Dio 5627 1: an instance of the cognitio is suggested by the similar application outside of Rome and the punishment inflicted "personally". 
or veiled insult a rare instance of a "Klagenkonkurrenz" between private and public iniuria, one that goes beyond physical injuries at that. So what happened in 6 AD? Were certain aspects of the delict iniuria pertaining to forms of veiled or indirect insults brought under the ambit of the lex Iulia de maiestate even if they had not been aimed at the Emperor but at the majesty of the Roman people as Tacitus states? Or is Tacitus inaccurate, and specie legis really entails an extension of the lex Cornelia de iniuriis? Or did the distinction not matter anymore already in $6 \mathrm{AD}$, since the senatus consultum brought a variety of indirect forms of defamatory libel under the scope of the emperor's cognitio? Various instances of circumstantial evidence can be presented in favour of the latter possibility: the (later) literary sources pertaining to indirect forms of defamatory libel, including Tacitus 1,72 , tend to suggest a personal jurisdiction of the emperor from Augustus onwards, employing terms such as cognitio. There are precedents for specific forms of iniuria such as that done by a slave being prosecuted extra ordinem even before Augustus; and the ground for the $6 \mathrm{AD}$ senatus consultum constituting problems of evidence fits well with the more extensive power of the magistrate in the context of the cognitio-trial. Yet, the more interesting conclusion concerns the dichotomy between public and private that plays throughout the distinction between various forms of iniuria. This distinction we may still see in modern systems of civil law: forms of libel that in one way or another affect the public good are prosecuted as crimes, whereas those that only concern the individual interest of the injured party are subject to claims under private law. In Roman law, there seems to be a connection between what constitutes the public good and the "difficulties of proof" when it came to more indirect or veiled forms of defamatory libel. Here, there is a clear and typically pragmatic ground for opting for a more-or-less public prosecution, due to the more extensive powers of the magistrate in the cognitio-trial, thus also safeguarding the private interest of the injured party. As Paul has it (D 3342 1): "Even though the actio [ex lege Cornelia de iniuriis, $\mathrm{JG}]$ is instituted for the public good, it is still a private one."

\section{BIBLIOGRAPHY}

Bauman, Richard (1970) The crimen maiestatis in the Roman Republic and Augustan Principate (Johannesburg)

Brown, Jonathan (2018) “'Revenge porn' and the actio iniuriarum: Using 'old law' to solve 'new problems"" in Legal Studies 38-3: 396-410

Buckland, William (1963) A Text-Book of Roman Law from Augustus to Justinian (Cambridge)

Daube, David (1991) “Ne quid infamandi causa fiat. The Roman law of defamation", in Collected Studies in Roman law I ed by D Cohen \& D Simon (Frankfurt am Main): 465-500

Descheemaeker, Eric \& Scott, Helen (2013) "Iniuria and the common law" in Iniuria and the Common Law Eric Descheemaeker \& Helen Scott (eds) (Oxford/Portland, OR): 1-31

Hackl, Karl (1976) Praeiudicium im klassischen römischen Recht (München) 


\section{JACOB GILTAIJ}

Hagemann, Matthias (1998) Iniuria. Von den XII Tafeln bis zur Justianischen Kodifikation (Köln/ Weimar/Wien)

Ibbetson, David (2013) "Iniuria. Roman and English" in Iniuria and the Common in Iniuria and the Common Law Eric Descheemaeker \& Helen Scott (eds) (Oxford/Portland, OR): 33-48

Kaser, Max \& Hackl, Karl (1996) Das römische Zivilprozeßrecht (München)

Lenel, Otto (1889) Palingenesia iuris civilis I-II (Leipzig)

Lenel, Otto (2010) Das Edictum Perpetuum. Ein Versuch zu seiner Wiederherstellung (Amsterdam/ Aalen)

Liebs, Detlef (1972) Die Klagenkonkurrenz im römischen Recht. Zur Geschichte der Scheidung von Schadenersatz und Privatstrafe (Göttingen)

Von Lübtow, Ulrich (1969) 'Zum römischen Injurienrecht”, Labeo 15-2: 131-167

Miglietta, Massimo (2001) Servus dolo occisus. Contributo allo studio del concorso tra 'actio legis Aquilice'e 'iudicium ex lege Cornelia de sicariis'(Napoli)

Mommsen, Theodor (1899) Römisches Strafrecht (Leipzig)

Pugliese, Giovanni (1941) Studi sull'iniuria (Milano)

Pugliese, Giovanni (1982) “Linee generali dell' evoluzione del diritto penale pubblico durante il principato" in Aufstieg und Niedergang der römischen Welt II.14 (Berlin/New York, NY): $722-789$

Raber, Fritz (1969) Grundlagen klassischer Injurienansprüche (Wien/Köln/Graz)

Scott, Helen (2013) "Contumelia and the South-African law of defamation" in Iniuria and the Common Law Eric Descheemaeker \& Helen Scott (eds) (Oxford/Portland, OR): 119-139

Tuori, Kaius (2016) The Emperor of Law. The Emergence of Roman Imperial Adjudication (Oxford/New York, NY)

Volkmann, Hans (1969) Zur Rechtsprechung im Principat des Augustus (München)

Zimmermann, Reinhard (1996) The Roman Law of Obligations (Oxford) 